\title{
Analisis Deskriptif tentang Tampilan Kinerja Aparatur Sipil Negara di Sekretariat Pemerintah Kota Kupang Nusa Tenggara Timur Indonesia
}

\author{
Fellyanus Habaora $^{1)}$, Jefirstson Richset Riwukore ${ }^{2)}$, Tien Yustini ${ }^{3)}$ \\ 1,) 2),3) Magister Manajemen, Universitas Indo Global Mandiri, Kota Palembang \\ Email:habaorafhomas@gmail.com ${ }^{1)}$,jefritson@uigm.ac.i ${ }^{2)}$ tien_yustini@uigm.ac.id ${ }^{3)}$
}

\begin{abstract}
The purpose of this research was to determine the performance of state civil servants at the Secretariat of the Government of Kupang City, East Nusa Tenggara, Indonesia through the effectiveness of performance indicators, namely quantity, quality, timeliness, cooperation, and self-quality. The research was conducted for 6 months, namely September 2019-February 2020. The total population and research sample were 370 ASN which were determined by purposive stratified proportional sampling based on the position, class, and rank of the ASN. The type of data used is primary data and secondary data obtained by means of questionnaires, observation, and documentation. Data analysis was carried out on performance indicators using descriptive analysis based on the average value of the Likert scale classification. The results showed that in general, the performance of ASN in the Regional Secretariat of the Kupang City Government was effective as indicated by the average performance score of 3.71 or high. This result is because the performance indicators show the results of high-value categories which include quantity (3.79), quality (3.71), timeliness (3.67), cooperation (3.70), and self-quality (3.69).
\end{abstract}

Keywords: quantity, quality, timeliness, cooperation, self-quality, performance

\section{ABSTRAK}

Tujuan penelitian ini untuk mengetahui tampilan kinerja aparatur sipil negara di Sekretariat Pemerintah Kota Kupang Nusa Tenggara Timur Indonesia melalui efektifitas indikator kinerja, yaitu kuantitas, kualitas, ketepatan waktu, kerjasama, dan kualitas diri. Penelitian dilaksanakan selama 6 bulan, yaitu September 2019-Februari 2020. Jumlah populasi dan sampel penelitian sebanyak 370 ASN yang ditentukan secara purposive stratified proporsional sampling berdasarkan jabatan, golongan, dan kepangkatan dari ASN. Jenis data yang digunakan adalah data primer dan data sekunder yang diperoleh dengan cara kuesioner, observasi, dan dokumentasi. Analisis data dilakukan terhadap indikator kinerja menggunakan analisis deskriptif berdasarkan nilai rata-rata penggolongan skala Likert. Hasil penelitian menunjukkan bahwa secara umum kinerja ASN di Sekretariat Daerah Pemerintah Kota Kupang telah efektif yang ditunjukkan dari nilai rata-rata kinerja sebesar 3,71 atau termasuk tinggi. Hasil ini karena indikator kinerja menunjukkan hasil kategori nilai yang termasuk tinggi yang meliputi kuantitas (3,79), kualitas (3,71), ketepatan waktu (3,67), kerjasama (3,70), dan kualitas diri $(3,69)$.

Kata Kunci: kuantitas, kualitas, ketepatan waktu, kerjasama, kualitas diri, kinerja

\section{Pendahuluan}

Organisasi merupakan kesatuan sosial yang dikoordinasikan secara sadar dengan sebuah batasan yang reaktif dapat diidentifikasikan, bekerja secara terus menerus untuk mencapai tujuan (Robbins, 2014). Untuk mencapai tujuan organisasi tersebut dibutuhkan berbagai macam sumber daya, dan salah satunya adalah sumber daya manusia yang ditentukan oleh kinerja pegawainya. Salah satu efektivitas kinerja yang dapat dikaji secara mendalam adalah kinerja birokrasi pemerintah yang selama ini diidentikkan dengan kinerja yang berbelitbelit dan buruk dalam pelayanan.

Laporan Badan Kepegawaian Nasional Republik Indonesia (2019) melaporkan bahwa hanya 20\% ASN di Indonesia yang memiliki kinerja dan prestasi pada kategori nilai amat baik. Artinya, masih terdapat kurang lebih $80 \%$ ASN yang dianggap memiliki kinerja dan prestasi yang buruk. Kondisi ini tidak berbeda jauh dari hasil penelitian dari PERC (Political and Economic Risk Consultancy) di tahun 1999 melaporkan bahwa Indonesia menjadi salah satu negara terburuk dalam bidang birokrasi di dunia dengan skor 8.0 dari skor 10 untuk yang terburuk (Komara, 2019).

Selain hal itu, laporan IFC: Doing Business Report tahun 2013 bahwa kinerja birokrasi di Indonesia menempati peringkat 128 pada tahun 2013 atau semakin buruk dibandingkan tahun 2007 yang menempati urutan 123 dunia, yang berarti bahwa kinerja birokrasi Indonesia dalam memberi pelayanan publik yang berorientasi pada kemudahan berusaha masih jauh dari harapan (Fauza \& Wismantoro, 2014). Hal ini mengindikasikan adanya prosedur dan mekanisme kerja yang berbelit-belit, tidak transparan, kurang informatif, 
kurang responsif, kurang konsisten sehingga tidak menjamin kepastian pelayanan.

Selanjutnya Institute for Management of Development, Swiss, World Competitiveness Book tahun 2007 melaporkan hasil survei terkait produktivitas kerja dalam kaitan dengan kinerja ASN pada tahun 2005 yang menghasilkan bahwa peringkat produktivitas kerja ASN Indonesia berada pada posisi 59 dari 60 negara yang disurvei, atau semakin turun dibandingkan pada tahun 2001 yang mencapai urutan 46, jauh dari negara Asia lainnya seperti Singapura (1), Thailand (27), Malaysia (28), Korea (29), Cina (31), India (39), dan Filipina (49). Komitmen yang rendah turut mempengaruhi kinerja sehingga Indonesia hanya berada diurutan paling akhir yakni ke 60 berdasarkan economic performance pada tahun 2005, Businees Efficiency (59), dan Goverment Efficiency (55). Hal ini karena mutu sumber daya manusia Indonesia yang tidak mampu bersaing, komitmen organisasi yang lemah, budaya kerja yang juga masih lemah dan tidak merata (Riwukore, 2010).

Pemerintah Kota Kupang dalam membangun daerahnya memiliki tujuh program pokok, yaitu: (1) penguatan ekonomi rakyat; (2) pengembangan pendidikan; (3) pengembangan kesehatan; (4) penegakan hukum, HAM dan peningkatan pertahanan keamanan, (5) pengembangan budaya politik dan birokrasi, (6) pengembangan aspek sosial kemasyarakatan, dan (7) pengembangan tata ruang. Untuk mewujudkan hal tersebut sangat dibutuhkan adanya komitmen organisasi dari ASN yang tinggi dan profesional.

Habaora (2015) menyatakan bahwa untuk meningkatkan kinerjanya, diperlukan perbaikan metode kerja sebagai upaya untuk meningkatkan kinerja, artinya untuk meningkatkan kinerja seseorang perlu memahami indikator pencapaian kinerja seperti dari aspek kualitas dan kuantitas, efisiensi dan efektivitas, perilaku dan ketepatan. Riwukore (2010) menyatakan bahwa pada prinsipnya kinerja seseorang ditentukan oleh tingkat kemampuan yang didasari kuantitas, kualitas, timelines, kerjasama, dan sikap. Dengan demikian kemampuan seorang pegawai mampu menunjukkan kinerja yang handal. Untuk hal tersebut perlu dilakukan penelitian yang mendalam terkait kinerja dari ASN di Sekretariat Daerah Pemerintah Kota Kupang.

\section{Landasan Teori \\ 2.1Kinerja}

Kinerja adalah hasil kerja yang dapat dicapai oleh seseorang kelompok atau sekelompok orang dalam suatu organisasi sesuai dengan wewenang dan tanggungjawab masing-masing, dalam rangka upaya mencapai tujuan organisasi bersangkutan secara legal, tidak melanggar hukum dan sesuai dengan moral dan etika (Prawirosentono, 2012). Kinerja dapat didefenisikan sebagai hasil kerja secara kualitas dan kuantitas yang dicapai oleh seorang pegawai dalam melaksanakan tugasnya sesuai dengan tanggungjawab yang diberikan kepadanya (Mangkunegara, 2017).

Kinerja merupakan hasil dan usaha seseorang yang dicapai dengan adanya kemampuan dan perbuatan dalam situasi tertentu (Riwukore, 2010; Heryati, 2018). Cahayani (2005) menyatakan bahwa kinerja merupakan gabungan perilaku dengan prestasi dari apa yang diharapkan dan pilihannya atau bagian syarat-syarat tugas yang ada pada masing-masing individu dalam organisasi. Soeprihantono (1998:9) mengatakan bahwa kinerja merupakan hasil pekerjaan seorang karyawan selama periode tertentu dibandingkan dengan berbagai kemungkinan seperti standar, target/sasaran/kriteria yang telah ditentukan terlebih dahulu dan telah disepakati bersama. Menurut Dessler (2016) dan Adipati (2018) bahwa kinerja adalah prestasi kerja, yaitu perbandingan antara hasil kerja yang dapat dilihat secara nyata dengan standar kerja yang telah ditetapkan organisasi.

Kinerja yaitu suatu hasil yang dicapai oleh pegawai dalam pekerjaannya menurut kriteria tertentu yang berlaku untuk suatu pekerjaan (Robbins, 2014; Calista, 2019). Kinerja mempunyai arti penting bagi pegawai karena adanya penilaian kinerja berarti pegawai mendapat perhatian dari atasan, disamping itu akan menambah gairah kerja pegawai karena dengan penilaian kinerja ini mungkin pegawai yang berprestasi dipromosikan, dikembangkan dan diberi penghargaan atas prestasi, dan sebaliknya (Fauza \& Wismantoro, 2014). Dengan demikian setiap pegawai dalam organisasi dituntut untuk memberikan kontribusi positif melalui kinerja yang baik, mengingat kinerja organisasi tergantung pada kinerja pegawainya.

\subsection{Efektivitas Kinerja Organisasi}

Efektivitas kinerja organisasi dalam melaksanakan pekerjaan menurut Agus (2001:36), pada hakekatnya para pekerja memerlukan rasa aman, yang mempunyai kaitan dengan (1) jaminan masa depan, (2) suasana organisasi yang memberikan kesempatan untuk berkembang, tanpa adanya ancaman-ancaman, dan (3) hubungan antara atasan dan bawahan yang manusiawi. Riwukore (2010:87) menyatakan bahwa efektivitas kinerja organisasi merupakan susunan dari beberapa orang secara rapi yang menggambarkan seluruh siklus input-proses-output untuk mencapai tujuan yang diharapkan. Efektivitas organisasi terdiri dari individu dan kelompok yang menghasilkan efektivitas organisasi sehingga organisasi bisa efektif jika mampu mendapatkan hasil karya yang lebih tinggi tingkatannya dari pada jumlah hasil karyanya setiap bagiannya.

Bedeain (1991:61) menyatakan bahwa semakin besar pencapaian tujuan-tujuan organisasi semakin besar efektivitas. Organisasi akan bertahan jika dapat pemasukan lebih besar dari yang dituntut untuk pengeluaran. Hal ini berarti bahwa efektivitas kinerja organisasi dapat dilihat dari besarnya pencapaian tujuan dan besarnya output. Zimmamoto (1992:42) menjelaskan definisi efektif sebagai pencapaian tujuan atau hasil yang dikehendaki tanpa menghiraukan faktor-faktor tenaga, waktu, biaya, pikiran, alat, dan lain-lain yang telah dikeluarkan. Efektivitas juga dapat dijelaskan sebagai kemampuan untuk memilih tujuan yang paling tepat atau peralatan yang tepat untuk pencapaian tujuan yang telah ditetapkan (Handoko, 2011). Efektivitas sebagai 
kemampuan tingkat pencapaian organisasi jangka pendek dan jangka panjang (Maulana \& Rachman, 2016; Welly, 2016)

\subsection{Indikator Kinerja}

Schuller \& Siusan (1992) dan Septiani (2018) menyatakan ada lima indikator kinerja, yaitu

1. kuantitas pekerjaan, yaitu jumlah atau banyaknya pekerjaan yang diselesaikan oleh pegawai berdasarkan jumlah kerja yang dihasilkan, lamanya menyelesaikan, pengaruh karyawan terhadap alur kerja umum dan kemampuan mengenai tugas-tugas penyuluhan tanpa melakukan kesalahan-kesalahan dalam menyelesaikannya;

2. kualitas pekerjaan, yaitu penilaian pekerjaan seorang pegawai terhadap mutu pekerjaan yang dilaksanakan berdasarkan standar kerja yang ditentukan baik dari aspek hukum, undang-undang, tugas pokok dan fungsi pegawai, serta peraturan yang harus diikuti oleh pegawai yang bersangkutan dalam menyelesaikan tugas-tugasnya. Jika hasil kerja yang dicapai seseorang sesuai dengan mutu yang telah ditetapkan berarti pegawai tersebut dianggap memiliki kompetensi dan kinerja baik sesuai dengan tujuan organisasi karena mutu pekerjaan merupakan bagian dari kinerja pegawai;

3. ketepatan waktu, yaitu jangka waktu penyelesaian suatu pekerjaan yang ditugaskan pada seorang pegawai dalam jangka waktu tertentu. Ketepatan waktu merupakan bagian dari kinerja, karena kinerja dapat dipengaruhi oleh kemampuan seorang pegawai untuk menyelesaikan pekerjaannya sesuai dengan standar waktu yang telah ditentukan. Pekerjaan berkualitas, cukup dalam jumlah, jika tidak didukung oleh pencapaian waktu penyelesaian yang tepat sesuai dengan standar, maka kinerja tidak dapat dikatakan baik;

4. kerjasama, yaitu kemampuan seorang pegawai untuk bekerja dalam tim dan kelompok dalam melaksanakan tugas yang harus diselesaikan secara bersama-sama dengan pegawai lain. Kemampuan seorang pegawai dalam beradaptasi dengan rekan kerja akan mempengaruhi kinerja kelompok. Beradaptasi dengan rekan kerja diartikan sebagai kemampuan seorang pegawai untuk menerima atas kelebihan dan kekurangan rekan, serta berorientasi terhadap mutu dan volumen pekerjaan sesuai dengan target waktu. Semakin tinggi respon para anggota tim dalam memberikan ide-ide ataupun buah pikiran dalam memecahkan suatu permasalahan akan meningkatkan kinerja;

5. sikap, yaitu kemandirian seorang pegawai dalam menyelesaikan tugas yang dibebankan kepadanya tanpa memerlukan pengawasan dari pihak penyelia. Kemandirian seorang pegawai dalam melaksanakan tugasnya dengan baik tanpa memerlukan pengawasan berarti pegawai tersebut telah memiliki kompetensi kerja, kerena kemandirian bekerja merupakan salah satu faktor yang bepengaruh terhadap kinerja pegawai.

\section{Metodologi}

\subsection{Waktu Penelitian}

Penelitian ini dilaksanakan selama 6 bulan, yakni mulai bulan September 2019 sampai dengan Februari 2020 di Sekretariat Pemerintah Daerah Kota Kupang Nusa Tenggara Timur. Penentuan populasi dalam penelitian sesuai petunjuk Sugiyono (2017) yaitu populasi merupakan wilayah generalisasi yang terdiri dari objek atau subjek yang mempunyai kualitas dan karakteristik tertentu yang ditetapkan oleh peneliti untuk dipelajari dan kemudian ditarik kesimpulannya.

Populasi dalam penelitian ini adalah Aparatur Sipil Negara (ASN) lingkup Pemerintah Kota Kupang Nusa Tenggara Timur golongan I sampai golongan IV sejumlah 4895 orang. Sampel adalah sebagian dari jumlah dan karakteristik yang dimiliki oleh populasi tersebut. Sampel berupa responden dalam penelitian ini dipilih secara acak menggunakan teknik penarikan sample dengan metode purposive stratified proporsional sampling (Sugiyono, 2017). Untuk menentukan jumlah sampel digunakan rumus Slovin (Riwukore \& Habaora, 2019) pada probabilitas error 0.05 (5\%) sehingga jumlah responden dalam penelitian ini sebanyak 370 orang ASN Pemkot Kupang yang terdiri atas ASN golongan I sebanyak 8 orang responden, golongan II sebanyak 80 orang responden, golongan III sebanyak 215 orang responden, dan golongan IV sebanyak 67 orang responden.

\subsection{Jenis dan Sumber Data}

Jenis data yang dipakai dalam penelitian ini adalah jenis data kuantitatif yang didapatkan dari data primer dan data sekunder sebagai data pendukung penelitian ini. Data primer merupakan data yang diperoleh dari sumbernya langsung, seperti data yang didapat dari penyebaran kuesioner/angket yang diisi responden, sedangkan data sekunder merupakan data yang diperoleh dari hasil kepustakaan dan data yang telah diolah seperti penelitian-penelitian terdahulu, jurnal, dan artikel yang dikumpulkan dari pencarian di internet yang relevan dengan penelitian. Sumber data melalui penyebaran kuisioner dan observasi. Kuisioner, pengumpulan data yang dilakukan dengan cara menyebarkan sejumlah daftar pertanyaan kepada responden. Kuisioner ini dimaksudkan untuk memperoleh jawaban responden tentang informatif kinerja pada ASN Pemerintah Kota Kupang Nusa Tenggara Timur.

\subsection{Variabel Penelitian}

Defenisi batasan operasional dan variabel dalam studi informatif ini adalah kinerja. Batasan operasional dan variabel menurut Sujarweni (2014) adalah sesuatu hal yang berbentuk apa saja yang ditetapkan oleh peneliti untuk dipelajari sehingga diperoleh informasi tentang hal tersebut, dan kemudian ditarik kesimpulannya. Adapun jenis-jenis variabel mengikuti petunjuk dari teori Schuller dan Siusan (1992), yaitu 
1. Kuantitas

2. Kualitas

3. Ketepatan Waktu

4. Kerjasama

5. Kualitas Pribadi a) Bertanggungjawab menyelesaikan pekerjaannya sesuai dengan jumlah tugas yang dibebankan kepadanya

b) Menyelesaikan pekerjaanya berdasarkan job deskripsi yang ditetapkan

a) Menyelesaikan pekerjaannya sesuai dengan prosedur kerja yang telah ditetapkan

b) Mampu memberikan perhatian besar dengan mengevaluasi sistem yang berjalan

a) Menyelesaikan pekerjaannya sesuai dengan prioritas

b) Menyelesaikan tugasnya sesuai dengan standar waktu yang ditetapkan

a) Mampu memberdayakan anggota, meningkatkan kinerja tim dan membuat setiap anggota merupakan bagian penting bagi keberhasilan tim

b) Mampu mengembangkan sikap kerjasama dengan anggota tim dan berupaya berkontribusi

a) Mampu memberikan perhatian khusus untuk pengembangan individu dengan mempertimbangkan potensi yang dimiliki

b) Memiliki inisiatif untuk melaksanakan tugasnya tanpa diperintah

\subsection{Analisis Data}

Metode analisis data yang digunakan dalam penelitian ini adalah analisis deskriptif berdasarkan nilai rata-rata penggolongan skala Likert menjadi tiga bagian menggunakan rumus:

$$
\frac{5-1}{3}=1,33
$$

Nilai rata-rata $1-2,32$ termasuk rendah Nilai rata-rata 2,33 - 3,65 termasuk sedang Nilai rata-rata 3,66 - 5,00 termasuk tinggi

\section{Hasil dan Pembahasan}

\subsection{Kuantitas Pekerjaan}

Indikator kinerja dari aspek kuantitas dapat diukur berdasarkan (1) tanggungjawab untuk menyelesaikan pekerjaannya sesuai dengan jumlah tugas yang dibebankan; dan (2) menyelesaikan pekerjaan berdasarkan job deskripsi yang ditetapkan. Indikator kinerja dari aspek kuantitas pada ASN di Sekretariat Pemerintah Daerah Kota Kupang tersaji pada Tabel 1. Berdasarkan Tabel 1, nilai rata-rata untuk subvariabel kuantitas menunjukkan: (1) pegawai bertanggungjawab menyelesaikan pekerjaannya sesuai dengan jumlah tugas yang dibebankan kepadanya, dengan nilai rata-rata sebesar 3,78 atau termasuk tinggi; dan (2) pegawai menyelesaikan pekerjaannya berdasarkan job deskripsi yang ditetapkan dengan nilai rata-rata sebesar 3,79 atau termasuk tinggi. Secara umum nilai rata-rata untuk subvariabel kuantitas pekerjaan sebesar 3,79 atau termasuk tinggi.

Hasil penelitian ini menunjukkan bahwa ASN dalam melaksanakan pekerjaannya sangat bertanggungjawab dan bekerja sesuai dengan job deskripsi masing-masing. Agar penyelesaian pekerjaan sesuai dengan jumlah tugas yang diberikan, pegawai Pemerintah Kota Kupang melakukan: mengatur waktu agar sesuai, bekerja cepat, berkoordinasi dan ambil keputusan cepat, bekerja dengan efektif dan efisien, teliti dan cermat, berkomitmen menyelesaikan tugas tersebut, disiplin dalam bekerja dan rasa tanggungjawab, menyusun program kerja. Agar pekerjaan berdasarkan job deskripsi yang ditetapkan, dilaksanakan bimbingan teknis, banyak belajar, bekerja dengan benar, disiplin dan loyalitas, konsisten pada pekerjaan, membuat rencana kerja, memperhatikan Standar of Procedure (SoP), pembagian tugas yang jelas, penyelesaian pekerjaan sesuai urutan tugas yang diberikan.

Secara umum tampilan kuantitas pekerjaan menunjukkan efektivitas yang baik. Dewi (2020) menyatakan bahwa adanya temuan pegawai yang dalam menyelesaikan pekerjaannya tidak tempat waktu dan asal-asalan saja karena sering menunda-nunda pekerjaan padahal pegawai telah membuat perencanaan kerja dan mengkomunikasikan dengan pimpinan. Hal itu didasarkan pada begitu banyak pekerjaan yang harus diselesaikan dan tentunya terdapat perintah-perintah dari atasan untuk mengerjakan pekerjaan lain yang menyebabkan pekerjaan tersebut tertunda. Meskipun demikian, kuantitas kerja yang dilakukan oleh ASN Pemerintah Kota Kupang telah sesuai dengan target yang dicapai sehingga secara keseluruhan hasil kerja pegawai cukup baik. Hal ini mencirikan terciptanya iklim kerja yang baik antara pegawai yang tentunya sangat efektif dalam pekerjaan yang dilakukan.

Tabel 1. Tanggapan responden tentang kuantitas pekerjaan

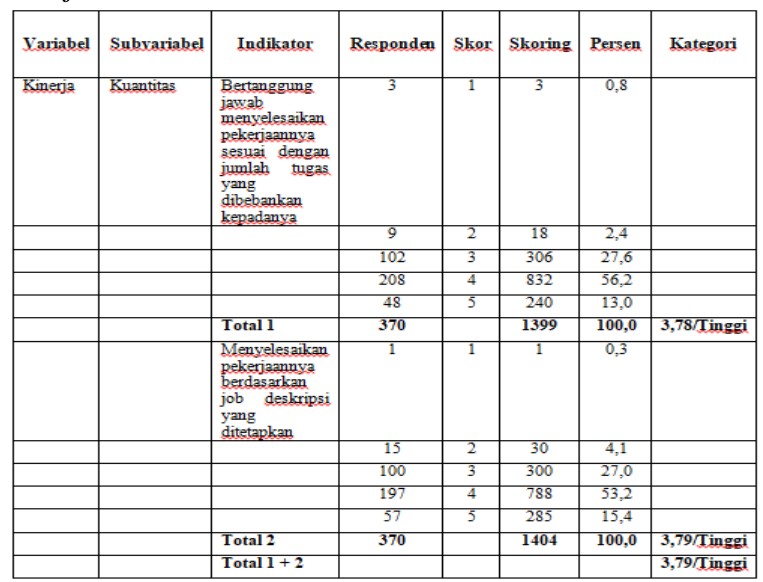

Iklim organisasi atau iklim kerja adalah lingkungan internal atau psikologi organisasi. Iklim organisasi 
mempengaruhi praktik dan kebijakan sumber daya manusia yang diterima oleh anggota organisasi (Moslehpour et al., 2019). Iklim organisasi adalah kualitas lingkungan internal yang relatif berlangsung lama, yang dialami oleh anggota organisasi, mempengaruhi perilaku setiap anggota (Glisson, 2015). Beberapa hasil penelitian melaporkan bahwa variabel iklim kerja berpengaruh terhadap kinerja (Rahsel, 2016), dan terdapat pengaruh Variabel disiplin kerja dan lingkungan kerja terhadap kinerja karyawan (Liestiani et al., 2019). Syelviani (2017) melaporkan bahwa ada pengaruh yang signifikan antara deskripsi kerja terhadap kinerja pegawai negeri sipil dengan nilai adjusted $\mathrm{R}$ square $72 \%$ yang artinya sebanyak $28 \%$ kinerja pegawai dipengaruhi oleh faktor lain. Adanya deskripsi pekerjaan diharapkan tugas-tugas yang diberikan pimpinan dapat dikerjakan tepat pada waktunya dan hasil yang baik dengan upaya menjelaskan tugas pokok dan fungsi masing-masing dari setiap klasifikasi jabatan untuk mengetahui dan memahami posisi masing-masing.

Yusuf (2018) melaporkan bahwa secara parsial maupun simultan ada pengaruh positif dan signifikan dari tanggungjawab kerja terhadap kinerja pegawai yaitu sebesar 29,8\%. Tanggungjawab merupakan kesanggupan untuk menyelesaikan pekerjaan yang dibebankan dengan sebaik-baiknya dan tepat pada waktunya serta berani menanggung resiko atas keputusan yang diambilnya. Habaora (2015) menyatakan bahwa ciri-ciri orang yang bertanggungjawab adalah: (1) memiliki sikap serta kesadaran yang tinggi dan menunjukkan rasa tanggungjawab yang besar terhadap pekerjaannya, (2) kesanggupan menyelesaikan pekerjaan yang dibebankan dengan baik serta tepat waktu, (3) berani menanggung resiko terhadap keputusan yang diambil, (4) bekerja secara tekun dan berdedikasi tinggi, dan (5) memberikan pelayanan yang optimal sesuai bidang tugas.

\subsection{Kualitas Pekerjaan}

Kualitas merupakan salah satu komponen dari kinerja yang terdiri atas: (1) kemampuan dalam menyelesaikan pekerjaan sesuai dengan prosedur kerja yang telah ditetapkan, dan (2) mampu memberikan perhatian besar dengan mengevaluasi sistem yang berjalan. Hasil pengukuran nilai rata-rata dari sub variabel kualitas tersaji pada Tabel 2. Nilai rata-rata kedua indikator kualitas pekerjaan dapat dijelaskan bahwa: pertama, pegawai menyelesaikan pekerjaannya sesuai dengan prosedur kerja yang sudah ditetapkan dengan nilai rata-rata 3,80 atau termasuk tinggi; dan kedua, pegawai mampu memberikan perhatian besar dengan mengevaluasi sistem yang berjalan agar menghasilkan peningkatan kualitas secara berkelanjutan dengan nilai rata-rata yaitu termasuk tinggi.

Pegawai berusaha menyelesaikan pekerjaannya sesuai dengan prosedur kerja yang dilakukan dengan cara bekerja berdasarkan prosedur, disiplin dan tanggung jawab, tidak menumpuk pekerjaan, komitmen tepat waktu dan sasaran, memperhatikan standar of procedure, mengerti dan memahami prosedur kerja. Selain itu, pegawai mampu memberikan perhatian besar dengan mengevaluasi sistem yang berjalan dengan cara: mengadakan pertemuan rutin, bekerja sesuai dengan tugas pokok, berkoordinasi dan evaluasi, komunikasi dan konsultasi, melihat kembali pekerjaan apa yang tidak bisa dikerjakan, membuat laporan bulanan dan tahunan, memperbaiki kesalahan yang ada, dan menganalisa data yang ada.

Irawati (2015) menyatakan suasana kerja yang positif akan menciptakan kualitas kerja yang kondusif bagi tercapainya tujuan organisasi. Kondisi ini didasarkan bahwa kualitas kerja seseorang berhubungan dengan perilaku manajemen organisasi, baik didalam maupun diluar pekerjaan. Usaha peningkatan kualitas pekerjaan seorang pegawai dapat memberikan positive feeling yang meluas, dan akhirnya akan berdampak terhadap peningkatan kinerja karyawan. Wujud dari implementasi kualitas kerja adalah menyelesaikan pekerjaan sesuai prosedur yang telah disepakati dan mampu memberikan perhatian melalui evaluasi pada sistem yang ada. Dengan demikian kualitas pekerjaan menghasilkan kegiatan yang dilakukan mendekati sempurna, dalam arti menyesuaikan beberapa cara ideal (prosedur kerja) dan penampilan kegiatan (perhatian) dalam memenuhi tujuan yang diharapkan dari suatu kegiatan.

Tabel 2. Tanggapan Responden tentang Kualitas Pekerjaan

\begin{tabular}{|c|c|c|c|c|c|c|c|}
\hline Variabel & Subyariabel & Indikator & Responden & Skor & Skoring & Persen & Kategori \\
\hline \multirow[t]{13}{*}{ Kinerja } & Kualitas & $\begin{array}{l}\text { Menyelesaikan } \\
\text { pekerjaannya } \\
\text { sesuai dengan } \\
\text { prosedur kerja } \\
\text { yang tela the telah } \\
\text { ditetapkan }\end{array}$ & 1 & 1 & 1 & 0,3 & \\
\hline & & & 13 & 2 & 26 & 3,5 & \\
\hline & & & 110 & 3 & 330 & 29,7 & \\
\hline & & & 181 & 4 & 724 & 48,9 & \\
\hline & & & 65 & 5 & 325 & 17,6 & \\
\hline & & Total1 & 370 & & 1406 & 100,0 & $3,80 /$ Tinggi \\
\hline & & $\begin{array}{l}\text { Mampu } \\
\text { memberikan } \\
\text { perthatian besar } \\
\text { dengan } \\
\text { mengevaluasi } \\
\text { sistem yang } \\
\text { berjalan }\end{array}$ & 2 & 1 & 2 & 0,5 & \\
\hline & & & 14 & 2 & 28 & 3,8 & \\
\hline & & & 151 & 3 & 453 & 40,8 & \\
\hline & & & 155 & 4 & 620 & 41,9 & \\
\hline & & & 48 & 5 & 240 & 13,0 & \\
\hline & & Total 2 & 370 & & 1343 & 100,0 & 3,63/Sedang \\
\hline & & Total 1 + 2 & & & & & 3,71/Tinggi \\
\hline
\end{tabular}

Hasil penelitian dari aspek perhatian terhadap sistem yang sedang berjalan pada indikator kinerja terhadap kualitas pekerjaan menunjukkan para pegawai kurang memperhatikan atau mengevaluasi sitem kerja yang sedang berjalan. Kemungkinan faktor yang sangat mempengaruhi adalah partisipasi yang masih bersifat pasif karena masing-masing pegawai telah memiliki job deskripsi masing-masing, dan juga kemungkinan dipengaruhi imbalan atau insentife yang dianggap kurang oleh pegawai.

Walton (1991) menyatakan bahwa indikator dalam kualitas kerja terdiri atas pertumbuhan dan pengembangan, partisipasi, sistem imbalan yang inovatif, dan lingkungan kerja. Faktor yang sering menjadi penghambat dalam kualitas kerja diantaranya adalah partisipasi dan sistem imbalan. Partisipasi, yaitu adanya kesempatan untuk berpartisipasi atau terlibat dalam pengambilan keputusan yang mempengaruhi langsung maupun tidak langsung terhadap pekerjaan, 
sedangkan sistem imbalan yaitu imbalan yang diberikan kepada karyawan memungkinkan mereka untuk memuaskan berbgaai kebutuhannya sesuai dengan standar hidup pegawai yang bersangkutan dan sesuai dengan standar pengupahan dan penggajian yang berlaku di pasaran kerja. Irawati (2015) melaporkan ada pengaruh yang posotif dan signifikan antara partisipasi dan imbalan terhadap peningkatan kualitas pekerjaan yang berdampak pada output kinerja pegawai.

\subsection{Ketepatan Waktu}

Ketepatan waktu merupakan tingkat aktivitas diselesaikan pada awal waktu yang dinyatakan, dilihat dari sudut koordinasi dengan hasil output serta memaksimalkan waktu yang tersedia untuk aktivitas lain (Robbins, 2014). Indikator dari ketepatan waktu dapat ditelaah dari dua hal, yaitu (1) menyelesaikan pekerjaannya sesuai dengan prioritas, dan (2) menyelesaikan tugasnya sesuai dengan standar waktu yang ditetapkan. Informasi dan data terkait tanggapan responden tentang ketepatan waktu tersaji pada Tabel 3. Hasil penelitian menunjukkan nilai rata-rata kedua indikator ketepatan waktu, yaitu: (1) pengawai menyelesaikan pekerjaannya sesuai dengan prioritas dengan nilai rata-rata sebesar 3,69 atau termasuk tinggi; (2) pegawai menyelesaikan tugasnya sesuai dengan standar waktu yang ditetapkan dengan nilai rata-rata sebesar 3,65 atau termasuk tinggi; dan (3) nilai rata-rata untuk ketepatan waktu sebesar 3,67 atau termasuk tinggi. Hasil penelitian ini menunjukkan bahwa pegawai dapat menyelesaikan pekerjaannya sesuai dengan prioritas dilakukan dengan cara bekerja dengan baik, bekerja sesuai skala prioritas, harus punya etos kerja dan disiplin, membuat agenda/prioritas kerja, teliti, tepat, cermat, bertanggungjawab. Selain itu, pegawai menyelesaikan tugasnya sesuai dengan standar waktu yang ditetapkan dilakukan dengan cara bekerja dan selesaikan pekerjaan tepat waktu, bekerja dengan tulus dan tanggungjawab, evaluasi tiap minggu dan bulanan, menyusun rencana kerja, tidak menunda pekerjaan. Ketepatan waktu merupakan salah satu cara untuk mengukur transparansi dan kualitas kinerja.

Menurut Mareta (2015), penyampaian informasi sedini mungkin sangat diperlukan agar dapat dipakai sebagai dasar dalam pengambilan keputusan dan mencegah agar terlambatnya pembuatan keputusan tersebut.

Tabel 3. Tanggapan responden tentang ketepatan waktu

\begin{tabular}{|c|c|c|c|c|c|c|c|}
\hline Variabel & Subvariabel & Indikator & Responden & Skor & Skoring & Persen & Kategori \\
\hline \multirow[t]{13}{*}{ Kinerja } & $\begin{array}{l}\begin{array}{l}\text { Keteppatan } \\
\text { wakth }\end{array} \\
\text { ing }\end{array}$ & 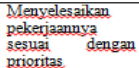 & 1 & 1 & 1 & 0,3 & \\
\hline & & & 5 & 2 & 10 & 1,4 & \\
\hline & & & 130 & 3 & 390 & 35,1 & \\
\hline & & & 204 & 4 & 816 & 55,1 & \\
\hline & & & 30 & 5 & 150 & 8,1 & \\
\hline & & Total 1 & 370 & & 1367 & 100,0 & 3,69/Tinggi \\
\hline & & 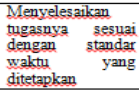 & 4 & 1 & 4 & 1,1 & \\
\hline & & & 9 & 2 & 18 & 2,4 & \\
\hline & & & 136 & 3 & 408 & 36,8 & \\
\hline & & & 184 & 4 & 736 & 49,7 & \\
\hline & & & 37 & 5 & 185 & 10,0 & \\
\hline & & Total 2 & 370 & & 1351 & 100,0 & 3,65/Tinggi \\
\hline & & Total 1 + 2 & & & & & 3,67/Tinggi \\
\hline
\end{tabular}

Ketepatan waktu yang tergolong tinggi pada ASN Pemerintah Kota Kupang menunjukkan bahwa ASN telah mampu menghargai waktu kerja karena waktu bersifat terbatas, sedangkan pekerjaan senantiasa bertambah. Ketepatan waktu juga untuk membantu ASN bekerja lebih efektif dengan skala prioritas. Secara psikis, ketepatan waktu menjauhkan ASN dari stress dan kerja asal-asalan dan dapat mengontrol setiap tugas dan tenggat waktunya. Ketepatan waktu akan menjadikan ASN lebih produktif atau dapat menghindari hambatan dan gangguan yang menghalangi dari tujuan. Habaora (2015) menyatakan bahwa ketepatan waktu yang sesuai dengan kebutuhan sangat membantu dalam menyelesaikan pekerjaan dalam waktu singkat dan menghasilkan beberapa manfaat, diantaranya: (1) membantu untuk membuat prioritas, (2) mengurangi kecenderungan untuk menunda-nunda pekerjaan, (3) menghindari tabrakan waktu, (4) memberi kebebasan dan kendali, (5) menghindari perasaan bersalah, dan (6) membantu mengevaluasi kemajuan pekerjaan.

\subsection{Kerjasama}

Peningkatan kinerja dan pencapaian tujuan organisasi, salah satunya ditentukan oleh faktor kerjasama tim yang kuat dan solid dalam organisasi. Hal ini yang akan menghasilkan keberhasilan tujuan organisasi. Indikator dalam kerjasama dapat dinilai berdasarkan dua hal, yaitu: (1) mampu memberdayakan anggota, meningkatkan kinerja tim dan membuat setiap anggota merupakan bagian penting bagi keberhasilan tim; dan (2) mampu mengembangkan sikap kerjasama dengan anggota tim dan berupaya berkontribusi. Hasil menunjukkan bahwa nilai rata-rata indikator kerjasama, yaitu: (1) pegawai mampu memberdayakan anggota, meningkatkan kinerja tim dan membuat setiap anggota merupakan bagian penting bagi keberhasilan tim dengan nilai rata-rata sebesar 3,67 atau tergolong tinggi; (2) pegawai mampu mengembangkan sikap kerjasama dengan anggota tim dan berupaya berkontribusi dengan nilai rata-rata sebesar 3,73 atau termasuk tinggi; dan (3) nilai rata-rata untuk kerjasama sebesar 3,70 atau tergolong tinggi.

Hasil penelitian ini menunjukkan bahwa pegawai mampu memberdayakan anggota dan meningkatkan kinerja tim melalui cara bekerjasama dan berkoordinasi, membagi tugas, memberi petunjuk, saling koreksi dan memberi masukan, memberikan kepercayaan dan kesempatan kepada rekan kerja, saling mendukung dan memotivasi. Selain itu pegawai mampu mengembangkan sikap kerjasama dengan anggota tim dan berupaya berkontribusi melalui cara berkomunikaso dengan baik dna bertukar pikiran, saling berkoordinasi dan berkonsultasi, membangun rasa memiliki dan tanggungjawab, mengetahui tugas, menghargai pendapat, menerima usul, keputusan dan kerjasama, profesional dan bertanggungjawab dalam tugas. 
Tabel 4. Tanggapan responden tentang kerjasama

\begin{tabular}{|c|c|c|c|c|c|c|c|}
\hline Variabel & Subyariabel & Indikator & Responden & Skor & Skoring & Persen & Kategori \\
\hline \multirow[t]{13}{*}{ Kineja } & Kerjasama & $\begin{array}{l}\text { Mampu } \\
\text { memberdayakan } \\
\text { anggota, } \\
\text { meningkatkan } \\
\text { kineja tim dan } \\
\text { membuat setiap } \\
\text { anggota merupakan } \\
\text { bagian penting bagi } \\
\text { keberhasilan tim }\end{array}$ & 2 & 1 & 2 & 0,5 & \\
\hline & & & 9 & 2 & 18 & 2,4 & \\
\hline & & & 144 & 3 & 432 & 38,9 & \\
\hline & & & 170 & 4 & 680 & 45,9 & \\
\hline & & & 45 & 5 & 225 & 12,2 & \\
\hline & & Total 1 & 370 & & 1357 & 100,0 & 3,67/Tinggi \\
\hline & & $\begin{array}{l}\text { Mampu } \\
\text { mengembangkan } \\
\text { sikap kerjasama } \\
\text { dengan anggota tim } \\
\text { dan berupaxa } \\
\text { berkontribusi }\end{array}$ & 0 & 1 & 0 & 0 & \\
\hline & & & 1 & 2 & 2 & 0,3 & \\
\hline & & & 134 & 3 & 402 & 36,2 & \\
\hline & & & 200 & 4 & 800 & 54,1 & \\
\hline & & & 35 & 5 & 175 & 9,5 & \\
\hline & & Total 2 & 370 & & 1379 & 100,0 & 3,73/Tinggi \\
\hline & & Total 1 + 2 & & & & & 3,70/Tinggi \\
\hline
\end{tabular}

Pratiwi, Ardianti dan Kanzunnudin (2018) menyatakan bahwa pembiasaan kerjasama dapat menghindari dan mengatasi sikap individualis dan egois. Kemampuan bekerjasama pada masing-masing orang dapat menciptakan sikap toleransi, dimana tindakan menghargai pendapat, sikap dan tindakan orang lain ang berbeda dengan dirinya. Kegiatan kerjasama memunculkan tindakan yang memperlihatkan rasa senang bergaul dengan orang lain melalui kegiatan kerjasama. Sucipto (2017) melaporkan bahwa kerjasama dapat membuat orang berpartisipasi penuh saat melaksanakan pekerjaan, setiap anggota memiliki tanggungjawab masing-masing dalam mengerjaka tugas sehingga tidak ada yang menganggap menumpang kepada anggota yang lain. Dominguez (2010) menjelaskan bahwa bekerja dengan orang lain mampu meningkatkan keterlibatan orang, berbagi ide-ide dan menanggapi reaksi orang lain meningkatkan pemikiran dan pemahaman mendalam. Maasawet (2011) menjelaskan bahwa kemampuan kerjasama akan meningkat dengan sendirinya apabila ada saling pengertian dan pemberdayaan. Indikatornya, (1) memberi informasi sesama anggota, (2) dapat menyelesaikan perselisihan yang terjadi, (3) menciptakan suasana kerjasama yang akrab, (4) bertukar ide dan pendapat kepada anggota lain, (5) mendukung keputusan organisasi, (6) menghargai masukan dan keahlian anggota lain, (7) berpartisipasi melaksanakan tugas, dan (8) menghargai hasil kerja organisasi.

\subsection{Kualitas Pribadi}

Keberhasilan atau kefektifan dalam proses organisasi dipengaruhi oleh kualitas pribadi dalam melakukan teknik atau ketrampilan dalam setiap tahap proses pekerjaan. Kualitas pribadi seseorang akan tampak dalam pemberian perhatian yang khusus terhadap pekerjaan dan memiliki inisiatif dalam proses pekerjaan. Indikator kualitas pribadi untuk ASN dilingkup Pemerintah Kota Kupang tersaji pada Tabel 5. Nilai rata-rata kedua indikator kualitas pribadi, yaitu (1) pegawai mampu memberikan perhatian khusus untuk pengembangan individu dengan mempertimbangkan potensi yang dimiliki dengan nilai rata-rata sebesar 3,72 atau termasuk tinggi; (2) pegawai memiliki inisiatif untuk melaksanakan tugasnya tanpa diperintah dengan nilai rata-rata sebesar 3,65 atau termasuk tinggi. Secara umum nilai rata-rata untuk kualitas pribadi sebesar 3,69 atau termasuk tinggi.

Hasil penelitian menunjukkan bahwa pegawai mampu memberikan perhatian khusus untuk pengembangan individu dilakukan dengan cara bekerja secara optimal dan bertanggungjawab, belajar banyak dari pengalaman, disiplin dalam tugas, mengikuti jenjang pendidikan yang lebih tinggi, dan mengikuti pelatihan. Selain itu, pegawai memiliki inisiatif untuk melaksanakan tugasnya tanpa diperintah melaui cara adanya tanggungjawab, bekerja sesuai aturan yang ada, melihat masalah yang ada di masyarakat, mempunyai ide-ide yang bagus, menciptakan pekerjaan tanpa menunggu perintah atasan, mengerti dan memahami uraian tugasnya. Haolah, Atus dan Irmayanti (2018) menyatakan bahwa kualitas pribadi dalam proses pekerjaan organisasi merupakan titik tumpu antara pengetahuan dan ketrampilan dari individu, atau dengan kata lain keberhasilan atau keefektifan dalam proses pekerjaan organisasi dipengaruh oleh kualitas pribadi dalam melakukan teknik atau ketrampilan dalam setiap tahap proses pekerjaan.

Tabel 5. Tanggapan responden tentang kualitas pribadi

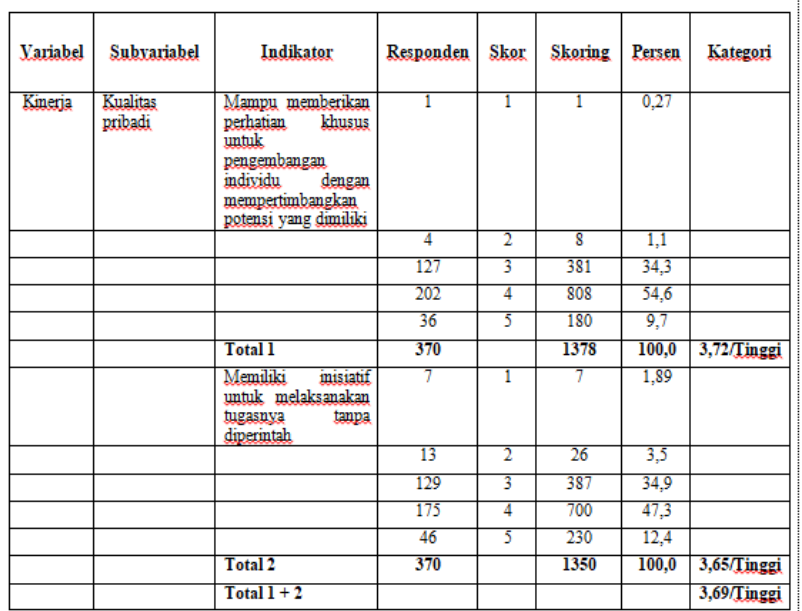

Memberikan perhatian yang khusus untuk pengembangan individu dengan mempertimbangkan potensi yang dimiliki sangat diperlukan karena kemampuan orang berbeda. Abidin (2016) melaporkan bahwa kualitas pribadi atau kualitas individu masingmasing manusia berbeda-beda untuk mengetahui, menganalisa dan meningkatkannya sehingga menyadari potensi dari masing-masing individu sangat diperlukan sehingga diperlukan adanya manajemen sumber daya manusia yang baik dan akurat. Apabila SDM telah diatur secara baik, inisiatif dengan sendirinya akan dilaksanakan tanpa menunggu arahan dan perintah atasan. Indikator kualitas pribadi ASN yang tinggi kemungkinan sangat dipengaruhi oleh faktor kepemimpinan, regulasi aturan, dan penggajian/insentif dari hasil kerja proyek yang dilakukan ASN,maupun motivasi. 
Habaora (2015) menyatakan bahwa peningkatan kualitas pribadi sangat ditentukan oleh banyak faktor, diantaranya adalah kepemimpinan, peraturan-peraturan, reward and punishment, dan motivasi pribadi. Faktor tersebut akan menjadi penghambat dalam peningkatan kualitas pribadi dalam suatu organisasi. Selanjutnya, Abidin (2016) menjelaskan bahwa strategi organisasi untuk menopang kualitas pribadi dengan cara memotivasi, memberi pengakuan individual, memberi kesempatan untuk melakukan kegiatan-kegiatan positif untuk pengembangan diri, melakukan pembinaan secara berkala, melakukan penilaian prestasi kerja, memberikan kompensasi, dan menciptakan hubungan kerja yang efektif.

\subsection{Tampilan Kinerja}

Kinerja merupakan tingkatan pencapaian hasil atas pelaksanaan tugas tertentu dalam rangka mewujudkan pencapaian hasil untuk mencapai tujuan. Manfaat dari penilaian kinerja adalah untuk peningkatan kinerja, pengembangan sumber daya manusia, pemberian kompensasi, program peningkatan produktivitas, program kepegawaian, menghindari perlakuan diskriminasi. Objek penilaian kinerja yaitu sifat yang dinilai dari orang yang memegang posisi pimpinan. Indikator kinerja dapat dinilai dari kuantitas dan kualitas pekerjaan, ketepatan waktu pekerjaan, kerjasama yang ada, dan kualitas pribadi. Nilai rata-rata indikator kinerja dari ASN di Pemerintah Kota Kupang dapat diperhatikan pada Tabel 6 .

Hasil penelitian menunjukkan bahwa kinerja ASN di lingkup Sekretariat Daerah Pemerintah Kota Kupang dapat dianggap berkinerja baik dan unggul. Hasil ini sesuai dengan nilai rata-rata dari keseluruhan indikator kinerja bernilai kategori tinggi dengan nilai rata-rata untuk kuantitas sebesar 3,79 (tinggi), kualitas sebesar 3,71 (tinggi), ketepatan waktu sebesar 3,67 (tinggi), kerjasama sebesar 3,70 (tinggi), dan kualitas pribadi atau sikap sebesar 3,69 (tinggi). Hasil penelitian ini menjelaskan bahwa kinerja ASN di Pemerintah Kota Kupang perlu dipertahankan dan ditingkatkan sehingga menjadi budaya organisasi atau iklim organisasi dalam mendukung pencapaian prestasi kerja dan kepuasan kerja. Mustika dan Utomo (2013) melaporkan bahwa ada pengaruh signifikan budaya organisasi terhadap kinerja karyawan melalui variabel kepuasan kerja sebagai variabel intervening.

Kusmaningtyas (2014) menyatakan bahwa apabila kinerja tercapai maka ada pengaruh signifikan dari iklim organisasi, komitmen organisasi, dan kepuasan kerja. Mannayong dan Djafar (2018) melaporkan bahwa kategori kinerja yang tinggi menunjukkan bahwa organisasi tersebut telah efektif karena ada pengaruh yang positif dan signifikan dari indikator kinerja seperti kualitas dan kuantitas hasil kerja, ketepatan menyelesaikan pekerjaan, prakarsa dalam menyelesaikan pekerjaan, kemampuan menyelesaikan pekerjaan, dan kemampuan membina kerjasama dengan pihak lain. Rindah (2017) menyatakan bahwa berhubungan dengan kinerja organisasi, maka ukuran baik buruknya kinerja diukur oleh efektivitas dan efisiensi. Efisiensi berkaitan dengan jumlah pengorbanan yang dikeluarkan dalam upaya pencapaian tujuan organisasi. Dalam suatu organisasi dapat dikatakan efisiensi apabila mencakup penggabungan proses kerja optimal dan rancangan dari peralatan dan fasilitas fisik lainnya dengan berdasarkan pada kegiatan kerja yang sudah masuk di dalam prosedur, susunan dan standar kinerja organisasi. Efektif apabila mencapai tujuan tersebut dapat dicapai sesuai dengan kebutuhan yang direncanakan.

Tabel 6. Tampilan kinerja ASN di Lingkup Sekretariat Pemerintah Kota Kupang

\begin{tabular}{|l|l|l|l|}
\hline Yariabel & Subvariabel & Nilai Rata-Rata & Kategori \\
\hline Kinerja & Kuantitas & 3,79 & Tinggi \\
\hline & Kualitas & 3,71 & Tinggi \\
\hline & Ketepatan waktu & 3,67 & Tinggi \\
\hline & Kerjasama & 3,70 & Tinggi \\
\hline & Kualitas pribadi & 3,69 & Tinggi \\
\hline & Nilai Rata-Rata & 3,71 & Tinggi \\
\hline
\end{tabular}

Masyita (2016) melaporkan bahwa kinerja pegawai yang efektif secara signifikan terhadap pelayanan yang maksimal. Purwito, Rachmawati dan Sutawa (2016) melaporkan bahwa pelayanan berkualitas menujukkan efektivitas kinerja dengan variabel lingkungan kerja atau iklim kerja sebagai variabel intervening. Aini (2019) menyatakan bahwa dampak dari organisasi yang memiliki kinerja tinggi akan berpengaruh terhadap pelayanan publik yang merupakan salah satu penunjang good governance dimana good governance sebagai tujuan utama dalam penyelenggaraan pelayanan kepada masyarakat. Sebagai goals, tentunya good governance membutuhkan proses penyelenggara pemerintah yang berkualitas, profesional, dan akuntabel yang ditunjukkan melalui kinerja pegawai.

Erawati, Darwis dan Nasrullah (2017) melaporkan bahwa efektifnya kinerja pegawai apabila indikator hasil kerja (kuantitas dan kualitas pekerjaan), perilaku (ketepatan waktu dan kualitas pribadi), atribut dan kompetensi yang ada kaitannya terhadap kerjasama bernilai kategori tinggi. Sebaliknya, Demmallino, Rahmadanih dan Aswar (2018) melaporkan bahwa pelaksanaan kinerja organisasi yang tidak efektif karena belum dapat memenuhi kebutuhan anggota baik kebutuhan alat pendukung, jaminan kuantitas, kualitas dan kontinuitas hasil, tidak mampu meningkatkan nilai tambah hasil kerja, dan tidak ada jaminan penciptaan usaha dan kemandirian anggota. Hasil penelitian yang menampilkan kinerja ASN Pemerintah Kota Kupang dengan kategori tinggi menunjukkan bahwa kualitas birokrasi pemerintahan di Kota Kupang cukup baik,

Meskipun masih terdapat indikator lain yang belum diteliti, seperti yang dikemukakan oleh Pratiwi dan Seran (2018) bahwa indikator prasyarat untuk memecahkan permasalahan kinerja ASN, yaitu kualitas pekerjaan, kuantitas pekerjaan, kerjasama tim, kreativitas, inovasi, dan inisiatif. Masing-masing indikator kinerja tersebut memerlukan konsep yang tepat untuk mewujudkan tujuan tercapainya peningkatan kinerja yang tentunya berpengaruh langsung terhadap output dan tujuan organisasi. Selain itu, efektivitas organisasi yang belum 
sepenuhnya maksimal disebabkan oleh penataan struktur organisasi yang tidak sesuai dengan beban kerja yang ada, lingkungan tempat kerja yang kurang memadai, baik itu dari sarana dan prasarana, pekerja yang kurang memiliki keahlian, serta kebijakan dan praktek manajemen dimana prosedur kerja tidak dapat berjalan sesuai yang diharapkan (Kasim 2015). Dengan demikian, secara umum faktor yang mempengaruhi kinerja ASN adalah produktivitas, kualitas pelayanan, responsivitas, responsibilitas, dan akuntabilitas (Rahman, 2017).

\section{Kesimpulan}

Hasil penelitian menunjukkan bahwa secara umum kinerja ASN di Sekretariat Daerah Pemerintah Kota Kupang telah efektif yang ditunjukkan dari nilai rata-rata kinerja sebesar 3,71 atau termasuk tinggi. Hal tersebut disebabkan karena indikator kinerja yang meliputi kuantitas, kualitas, ketepatan waktu, kerjasam, dan kualitas diri menunjukkan performa yang tinggi. Tampilan kinerja seperti ini perlu dipertahankan dan tingkatkan terutama yang terkait dengan aspek kualitas dimana masing menunjukkan perhatian ASN terhadap evaluasi sistem yang sedang berjalan masih berkategori sedang.

\section{Daftar Pustaka}

Abidin, A. A. (2016). Encouraging the improvement of personal qualities to improve the quality of institutions (Study of human resource management at MI AL Illahiya Rejoagung Ngoro Jombang). Modeling: Jurnal Program Studi PGMI, 3(2), 174-186.

Adipati, K. (2018). Pengaruh Kompensasi terhadap Motivasi Kinerja Karyawan pada PT. Mncleasing Palembang. Jurnal Ilmiah Ekonomi Global Masa Kini, 8(2), 74-78.

Agus, E. M. (2001). Media psikologi INSAN. Surabaya: Lembaga Pengkajian dan Pengembangan Psikologi Terapan (LP3T) Fakultas Psikologi UNAIR

Aini, N. (2019). Evaluasi kinerja pegawai untuk mewujudkan pelayanan publik dalam perspektif good governance. Jurnal Inovasi Ilmu Sosial dan Politik, 1(1), 43-57. doi:10.33474/jisop

Bedeain, A. G. (1991). Organization (theory and desighn). Denver: University of Colorado Press.

Cahayani, A. (2005). Strategies and policy of human resource management. Jakarta: PT. Indeks.

Calista, A. (2019). Kemampuan dan Kedisiplinan Kerja terhadap Kepuasan Kerja Serta Dampaknya pada Kinerja Pegawai Dinas Perhubungan, Komunikasi dan Informatika Kabupaten Musi Banyuasin. Jurnal Ilmiah Ekonomi Global Masa Kini, 9(2), 145-150.

Demmallino, E. B., Rahmadanih, \& Aswar. (2018). Effectiveness of the organizational performance of Pottanae Group of combined farmers. Jurnal Sosial Ekonomi Pertanian, 14(3), 285-296.

Dessler, G. (2016). Manajemen sumber daya manusia. Jakarta (ID): PT. Salemba Empat.
Dewi, V. (2020). The effectiveness of the performance of civil servants at the Subdistrict Office of Simpang Rimba, South Bangka District (Judging from Law Number 5 of 2014 regarding State Civil Apparatus). The Journal Justici, 12(2), 6473.

Dominguez, D. (2010). Good practice encourages cooperation among students. Journal of Legal Education, 49, 386-400.

Erawati, I., Darwis, M., \& Nasrullah, M. (2017) Efektivitas kinerja pegawai pada Kantor Kecamatan Palangga Kabupaten Gowa. Jurnal Office, 3(1), 13-18.

Fauza, D. H., \& Wismantoro, Y. (2014). Factors analysis that influence of state civil apparatus performance in Badan Pertanahan Nasional of the Boyolali District. Media Ekonomi dan Teknologi Informasi, 22(1), 71-89.

Glisson, C. (2015). The role of organizational culture and climate in innovation and effectiveness. Human Service Organizations, Management, Leadership \& Governance, 39(4), 245-250. doi:10.1080/23303131.2015.1087770

Habaora, F. (2015). Inspiration of politics education (Inspirasi pendidikan politik). Jakarta, Indonesia: JP II Publishing House.

Habaora, F. (2015). Opinion population in abuse of power (Populasi opini penyalahgunaan kekuasaan). Yogyakarta, Indonesia: Deepublish Press.

Handoko, T. H. (2011). Manajemen personalia dan sumber daya manusia. Yogyakarta: Badan Penelitian Fakultas Ekonomi (BPFE) Press.

Haolah, S., Atus, \& Irmayanti, R. (2018). The importance of the personal quality of the counselor in the implementation of individual counseling. Fokus, 1(6), 215-226.

Heryati, A. (2018). Hubungan Antara Pendidikan dan Pelatihan (Diklat) K3 dan Pemberian kompensasi Terhadap Kinerja Karyawan PT. Kereta Api Indonesia (Persero) Devisi Regional III Palembang. Jurnal Ilmiah Ekonomi Global Masa Kini, 9(1), 71-76.

Irawati, S. A. (2015). Pengaruh kualitas kehidupan kerja terhadap kinerja pegawai Dinas Perindustrian dan Perdagangan Kabupaten Sampang. Neo-Bis: Jurnal Berkala Ilmu Ekonomi, 9(2), 41-52. doi:https://doi.org/10.21107/nbs.v9i2.1272

Kasim, M. A. (2015). Analyzing the organizational effectiveness on the Office of Technical Implementation Unit (UPTD) of Tolitoli Representative in Palu. E-Jurnal Katalogis, 3(11), 151-161.

Komara, E. (2019). Professional competence of State Civil Apparatus in Indonesia. Mimbar Pendidikan: Jurnal Indonesia Untuk Kajian Pendidikan, 4(1), 73-84.

Kusmaningtyas, A. (2014). Performance of State Civil Apparatus in Mataram City Goverment. Ekuitas: Jurnal Ekonomi dan Keuangan, 18(4), 487-506. 
Liestiani, N. L., Perizade, B., Hanafi, A., \& Zunaidah. (2019). The effect of work discipline and work environment on the performance of $\mathrm{Al}$ Hudori Cooperative of Palembang employess. Journal of Economics and Bussiness, 2(1), 61-72. doi:10.31014/aior.1992.02.01.67

Maasawet, E. T. (2011). Improve the ability to collaborate in learning biology through the implementation of guided inquiry strategies in grade VII students of SMP Negeri 6 Kota Samarinda in the 2010/2011 academic year. Jurnal Bioedukasi, 2(1), 1-13. doi:http://dx.doi.org/10.24127/bioedukasi.v2i1.19 7

Mangkunegara, A. P. (2017). Manajemen sumber daya manusia (Cetakan Ketiga ed.). Bandung: Alfabeta Press.

Mannayong, J., \& Djafar, R. (2018). Effectiveness of employees performance at Youth and Education and Sport Departement of Takalar District. Jurnal Administrasi Negara, 24(2), 77-88.

Mareta, S. (2015). Analyze factors that affect timeliness of the Indonesian public company's financial statement forwading in periode of 2009-2010 (Case study at Bursa Efek Indonesia). Jurnal Akuntansi, 19(1), 93-108.

Masyita, S. (2016). Effectiveness performance of employees in community services for making EKTP at the Office of Bontoa Subdistrict, Maros District. Jurnal Ilmiah Bongaya (Manajemen dan Akuntansi), 21, 236-249.

Maulana, M., \& Rachman, B. (2016). Harga pembelian pemerintah (HPP) gabah-beras tahun 2010: Efektivitas dan implikasinya terhadap kualitas dan pengadaan Dolog. Analisis Kebijakan Pertanian, 9(4), 331-347.

Moslehpour, M., Altantsetseg, P., Mou, W., \& Wong, W. K. (2019). Organizational climate and work style: The missing links for sustainability of leadership and satisfied employees. Sustainability, $\quad 11(125), \quad 1-17$. doi:10.3390/su11010125

Mustika, A., \& Utomo, H. (2013). Pengaruh budaya organisasi terhadap kinerja karyawan dengan variabel kepuasan kerja sebagai variabel intervening (Studi kasus pada Koperasi Simpan Pinjam Gradiska Kecamatan Tuntang Kabupaten Semarang Tahun 2013). Jurnal Among Makarti, 6(12), 87-111.

Pratiwi, D., \& Seran, S. T. (2018). ASN performance improvement strategy through the Work Si Kerja application at IPDN West Kalimantan Campus. Transformasi: Jurnal Manajemen Pemerintahan, 10(2), 165-176.

Pratiwi, I. A., Ardianti, S. D., \& Kanzunnudin, M. (2018). The ability of cooperation and student learning outcomes using edutainment-based project-based learning model in social science subjects. Jurnal Refleksi Edukatika, 8(2), 177182.
Prawirosentono, S. (2012). Management of human resource, employee performance policy, strategy of organization development competitives in era of world free trade. Yogyakarta: BPFE Press.

Purwito, A. R., Rachmawati, K., \& Sutawa. (2016). Efektivitas kinerja pegawai dan kualitas pelayanan dalam perspektif iklim organisasi dan lingkungan kerja pada Kantor Bappeda Kabupaten Ngawi. Ekuilibrium : Jurnal Ilmiah Bidang Ilmu Ekonomi, 11(2), 99-106.

Rahman, T. (2017). Kinerja aparatur sipil negara dalam pelayanan publik (Studi deskriptif di Kelurahan Long Kali Kabupaten Paser). eJournal Ilmu Pemerintahan, 5(2), 661-672.

Rahsel, Y. (2016). The influence of motivation and work climate to Employee's Work Performance at the center Administration Of Bandung Padjadjaran University (study at general administration of Padjadjaran University). Jurnal Manajemen Magister, 2(1), 105-117.

Rindah. (2017). Analysis of the performance of state civil servants in the Regional Education and Culture Office of Central Sulawesi Province. EJurnal Katalogis, 5(1), 109-119.

Riwukore, J. R. (2010). Effect of transformational leadership, competency motivation and commitment to work organization and performance of employees in Goverment Secretariat City Kupang, East Nusa Tenggara [Disertasi]. Surabaya: Program Doktor Ilmu Ekonomi, Program Pascasarjana, Universitas 17 Agustus 1945.

Robbins, S. P. (2014). Organizational behavior. Jakarta: Salemba Empat Press.

Schuller, S. R., \& Siusan, J. E. (1992). Manajemen sumber daya manusia menghadapi abad-21 (Edisi Keenam (terjemahan) ed.). Jakarta: Erlangga.

Septianti, D. (2018). Pengaruh Kemampuan Kerja dan Motivasi Ekstrinsik Terhadap Kinerja Karyawan Pada CV. Pesona Palembang. Jurnal Ilmiah Ekonomi Global Masa Kini, 9(1), 38-46.

Soeprihantono, J. (1998). Penilaian pelaksanaan pekerjaan dan pengembangan karyawan. Yogyakarta: BPFE Press.

Sucipto, H. (2017). Application of a project-based learning model to increase interest and social studies learning outcomes. Jurnal Pendidikan: Riset \& Konseptual, 1(1), 77-86.

Sujarweni, W. V. (2014). Methodology of research. Yogyakarta: Pustaka Baru Press.

Syelviani, M. (2017). The effect of job description on civil servant's performance in Tembilahan Subdistrict Office. Journal of Economy, Business and Accounting, 1(1), 43-55. doi:https://doi.org/10.31539/costing.v1i1.48

Welly, W. (2016). Efektifitas Penyelenggaraan dan Pengelolaan Dana Program Nasional Pemberdayaan Masyarakat (PNPM) Mandiri Perkotaan di Kecamatan Ilir Timur II 
Palembang. Jurnal Ilmiah Ekonomi Global Masa Kini, 7(2), 16-22.

Yusuf, N. (2018). The influence of leadership, responsibility, discipline and cooperation on employee performance at the University of Gorontalo. Gorontalo Development Review, 1(1), 15-28. doi:https://doi.org/10.32662/golder.v1i1.111

Zimmamoto, R. (1992). Organisasi theory (Integrating structure and behavior). London: Prentice Hall New York. 